\title{
The rapid soybean growth in Brazil
}

\author{
Alexandre José Cattelan* and Amélio Dall'Agnol \\ Embrapa Soja, Rodovia Carlos João Strass, Acesso Orlando Amaral, CEP 86001-970, Londrina, PR, Brazil
}

Received 4 September 2017 - Accepted 19 December 2017

\begin{abstract}
Soybean is the main crop in Brazil, both in scale and in value. Nonetheless, the beginning was very humble. Soybean was a minor crop until the 1960s, when it was restricted to the South Region (subtropical), from where it expanded to the Midwest Region (tropical) in the 1980s. That was possible thanks to the development of cultivars well adapted to low latitude conditions of the Region. In the Midwest Region, home of the Cerrado Biome, the land was plentiful and affordable with flat topography, deep soils, well drained and easy to handle. The challenge was related to soil fertility, originally acidic and poor in nutrients. The role of research was of fundamental importance in overcoming that challenge. In the 1990s, soybean advanced towards the north center and in the 2000 s, it expanded farther to the north (latitudes near $0^{\circ}$ ). Soybean has been the driving force behind Brazil's recent agricultural development, with significant economic and social impact. Municipalities that grow soybean have achieved Human Development Indexes higher than the ones that do not grow soybean. Second place among the world's largest producers, Brazil is expected to take the lead in the coming decade. To move forward, Brazil needs to use the assets it already has: technological efficiency for production in tropical lands, availability of arable lands and entrepreneurial farmers. The global demand for soybean and the associated market prices will determine how much Brazilian soybean production will grow in the coming years.
\end{abstract}

Keywords: Cerrado / tropical soybean / Brazilian economy / HDI / sustainability

Résumé - La rapide croissance du soja au Brésil. Le soja est la principale culture actuellement au Brésil, à la fois en tonnage (hors canne à sucre) et en valeur. Dans les années 1960, sa production se limitait à la région du Sud (subtropicale); ensuite, dans les années 1980, il s'est étendu à la région du Centre-Ouest (tropicale). Cette expansion a été rendue possible grâce au développement de cultivars adaptés. Dans le Centre-Ouest, correspondant à la savane du Cerrado, la terre était abondante et abordable, avec une topographie plate, des sols profonds, bien drainés et faciles à travailler. Le défi était lié à l'amélioration de la fertilité des sols, à l'origine acides et pauvres en nutriments. Le rôle de la recherche a été fondamental. Dans les années 1990, le soja a progressé vers le Centre-Nord et dans les années 2000, il s'est étendu plus au Nord. Il est donc le moteur du développement agricole récent du Brésil, avec un impact économique et social important. Les communes où il est cultivé ont atteint des indices de développement humain (IDH) plus élevés que celles où il n'y en a pas. Deuxième producteur mondial, le Brésil devrait accroître encore son hégémonie du fait de son efficacité technologique, de la disponibilité de terres arables et du caractère entreprenant de ses agriculteurs, et sachant que la demande internationale et les prix associés détermineront cette croissance.

Mots clés : Brésil / Cerrado / soja / IDH / durabilité

\section{Introduction}

From all perspectives, soybean is the main crop in Brazil, including area and production. Nonetheless, it was not always that way. In 1960, soybean was a minor crop, when the

\footnotetext{
*Correspondence: alexandre.cattelan@embrapa.br; ajcattelan@gmail.com
}

production was just around 200000 metric tons (t). At that time, United States of America (USA) was already the number one grower with a production of 15 million $\mathrm{t}(\mathrm{Mt})$ and China was second, with $8.5 \mathrm{Mt}$. USA is still the major grower followed closely by Brazil, and Argentina comes next in third place (USDA/NASS, 2017; CONAB, 2017). The three countries account for $80 \%$ of the world soybean production, which is nearly $350 \mathrm{Mt}$ (Fig. 1) 


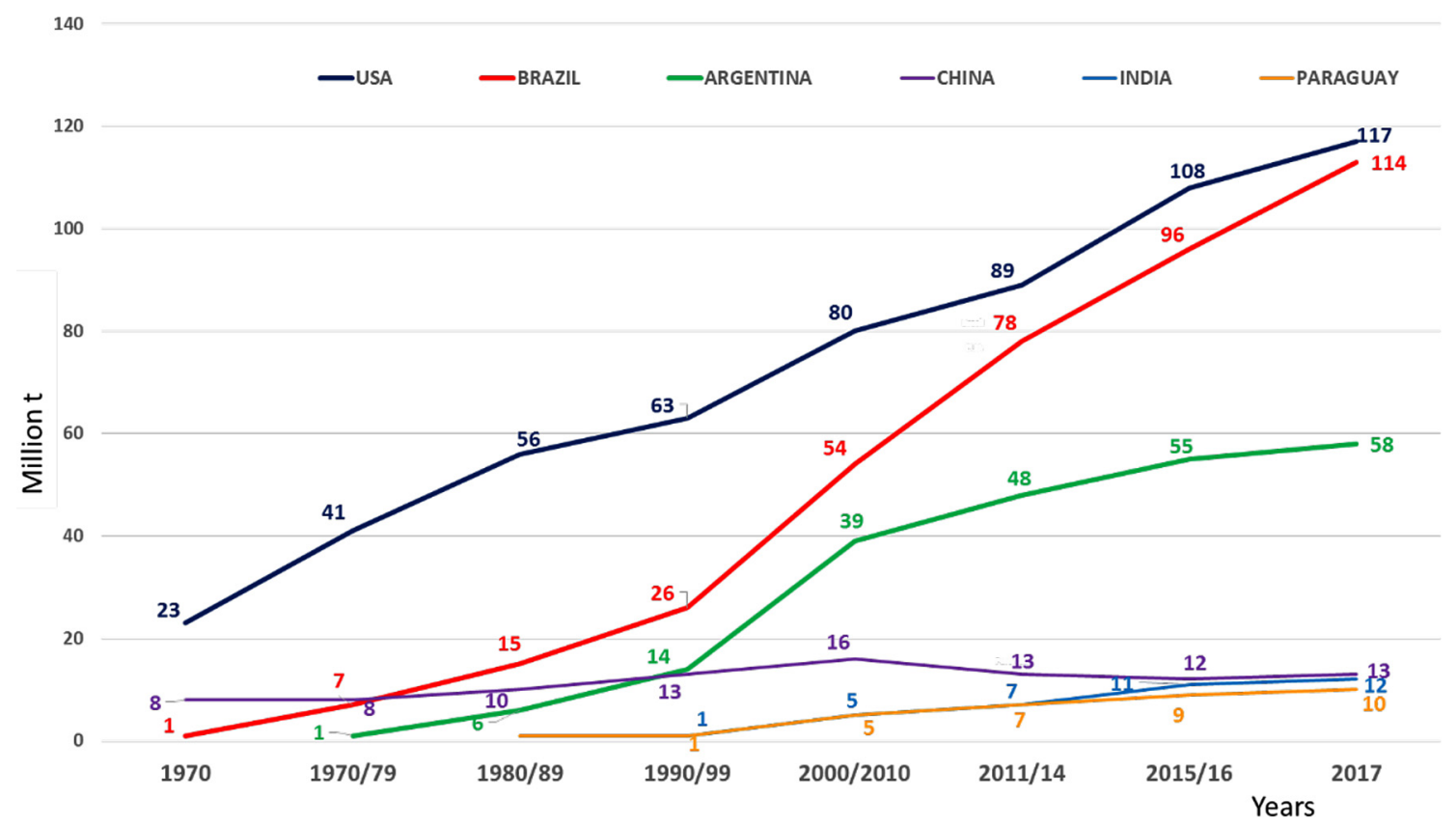

Fig. 1. Soybean production in the major producing countries - 1970 to 2017 (Adapted from USDA/NASS, 2017; CONAB, 2017).

This paper intends to present and discuss the early beginnings of soybean in Brazil, the challenges faced, the reasons for its growth, and the environmental, social and economic consequences of it. It also addresses the importance of Brazilian soybean for the world and the perspectives of it.

\section{The initial developments of the soybean crop in Brazil}

Soybean arrived in Brazil, introduced from the USA, in 1882. It entered via Salvador, Bahia State (Northeast Region), where latitude is low (around $12^{\circ} \mathrm{S}$ to $13^{\circ} \mathrm{S}$ ) and the climate is tropical. The American cultivars tested were adapted to temperate climate (latitudes near or higher than $30^{\circ}$ ), so they bloomed early, did not develop satisfactorily, resulting in low yields. Because of that, until 1980, soybean was restricted to the south of the country (temperate and subtropical region).

Only after more than half a century of its arrival in Brazil, American soybean genotypes were screened for the conditions of the Brazilian South Region. Initially, the adapted germoplasm was used for the production of biomass for feeding cattle, and the few grains produced were used for feeding pigs on farm. After the 1940s, soybean progressively toggled from biomass production to grain-producing crop. During that decade, production increased from a mere $457 \mathrm{t}$ in 1941 to $25881 \mathrm{t}$ in 1949 , the year Brazil first figured in international statistics as a producer of the oilseed (Dall'Agnol, 2016).

The fast expansion actually began in the 1960s, when a government program to boost Brazilian wheat production was launched in the southernmost state of Brazil, Rio Grande do Sul. This program also benefited soybean as the crop entered the summer season in succession with wheat in the winter (leguminous and grass succession) to optimize the use of land as well as of agricultural machinery. Other important cause of the advance of soybean in Brazil that time was the exceptional price of the grain on the world market in the mid-1970s (in 1973, the grain reached the highest value in history: US \$ $474.00 / \mathrm{t}$, equivalent to US $\$ 1249.00 / \mathrm{t}$ nowadays, at the Chicago Board of Trade-CBOT).

From the South Region, it expanded to the Midwest (tropical region) in the 1980s. That was possible thanks to the development of cultivars well adapted to the low latitude of the region, since the new cultivars were less sensitive to photoperiodic variations (daylight span). In the 1990s, soybean advanced towards the center north of the country (around $10^{\circ} \mathrm{S}$ to $12^{\circ} \mathrm{S}$ ) and in the $2000 \mathrm{~s}$, it expanded farther to the north (latitudes near $0^{\circ}$ to $5^{\circ} \mathrm{S}$ or $5^{\circ} \mathrm{N}$ ). The importance of soybean for the Brazilian agricultural development has been so significant that it is possible to divide the expansion of the sector into two periods: before and after soybean. Also, it is possible to divide soybean development into two stages: development in the subtropics (up to 1980) and expansion in the tropics (from the 1980s on).

The boom of the soybean production was accompanied by the production of other crops, with special emphasis on maize. Both crops together account for more than $80 \%$ of the total area and $85 \%$ of the production of grains in the country, whose growth in the period 1990-2017 was expressive (313\% against only $76 \%$ in the increase of area), indicating that the increase in productivity was also significant (Fig. 2). The soybean revolution, accompanied by the development of other crops, transformed Brazil from a food importer in the 1960's to one of the major exporters in the 2000's.

It is important to point out that the area cropped with soybean in 1970 (1.3 Mha) was the smallest when compared to 


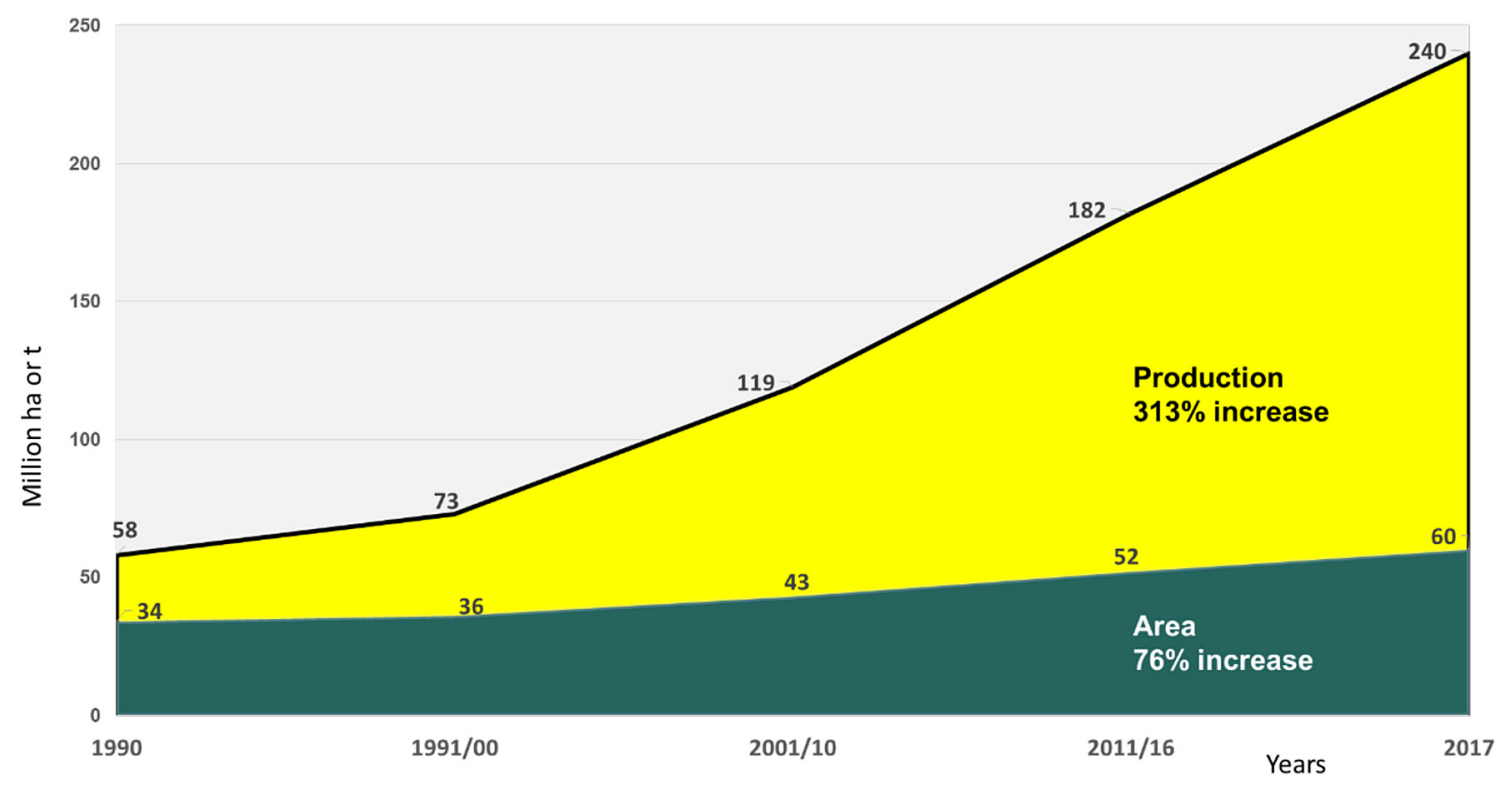

Fig. 2. Cropped area and grain production in Brazil-1990 to 2017 (Adapted from CONAB, 2017).

the seven main crops of that time (maize, wheat, rice, common beans, coffee, cotton and sugar cane). Today, soybean cropped area is similar to the sum of the areas of the other seven crops together (Fig. 3).

\section{Expansion of soybean cultivation towards the Cerrado}

As a result of the scarcity of areas suitable for soybean cultivation in the south of the country, and the clear signs that soybean would continue to be a good business for Brazilian producers, many southern farmers migrated to the savannahs $\left(\right.$ Cerrado $\left.^{1}\right)$ in the Midwest of the country. There, the land was plentiful and affordable, with flat topography and deep, well drained and easy to handle soils. Many farmers bought these lands for ridiculous amounts and others rented the land, fearing that they would not succeed and were forced to return to the south. Many of the region's current producers and even landowners also rent additional areas to increase their production potential. Others are just tenants.

\footnotetext{
${ }^{1}$ The Cerrado is a tropical savannah ecoregion located mostly in the Midwest Region of Brazil. It comprises part of many states including Bahia, Goiás, Maranhão, Mato Grosso, Mato Grosso do Sul, Minas Gerais, and Tocantins. Annual temperatures average between 22 and $27^{\circ} \mathrm{C}$ and average precipitation between $800-2000 \mathrm{~mm}$. There are two dominant seasons throughout the year, a rainy season from October until March and a very strong dry season from April until September. The vegetation is heterogeneous and usually, is divided into four categories: campo sujo (herbaceous layer with occasional small trees about $3 \mathrm{~m}$ tall), campo cerrado (herbaceous layer with slightly higher density of trees about $4 \mathrm{~m}$ tall on average), cerrado sensu stricto (orchard-like vegetation with trees about $6 \mathrm{~m}$ high) and cerradão (canopy cover near $50 \%$ with general height $9 \mathrm{~m}$ ) (Goodland, 1971).
}

Nevertheless, the soil was acidic and poor in nutrients. Nowadays, Cerrado is the main producing region of soybean, maize, cotton and meats.

The Cerrado Biome is located in a tropical region of low and medium latitudes and is characterized by dry winters and rainy spring/summer. Its area exceeds 200 Mha (Fig. 4). From the total area, $165 \mathrm{Mha}$ is arable land and only about $30 \mathrm{Mha}$ are currently occupied with crops. The remainder consists mostly of native vegetation and pasture fields, either native or improved, which could be turned into soybean production, if demanded (IBGE, 2017).

Although the region has extremely dry winters, spring crops are rarely hampered by water deficiencies, as eventually occurs in the subtropical region. The rainfall regime (late September through March/April) is fairly regular, allowing early soybean cultivation established early in the spring to be followed by second crop of maize (can be cotton, sunflower or other). That is feasible provided both crops are established in the no-till system, to avoid delays in sowing and loss of moisture caused by turning over the soil (plowing) in the conventional tillage.

Nevertheless, the beginning was hard for the dedicated entrepreneurs who left the more fertile and developed South Region to face the unknown Cerrado, a depopulated, devalued and discredited region ("Cerrado, neither given nor inherited", a popular saying used to state). The frustrations of the first harvests with the varieties brought from the south and successfully cultivated in this region alarmed the producers who demanded urgent actions to enable the cultivation of soybean for the low latitude conditions of the Cerrado. Efforts were immediately undertaken by Embrapa and other research institutes, with emphasis on the Agronomic Institute of Campinas, the Federal University of Viçosa and the Agricultural Research Agency of Goiás State, that developed the "Tropical Soybean", adapted to the tropical conditions of cultivation in Midwest Brazil. 


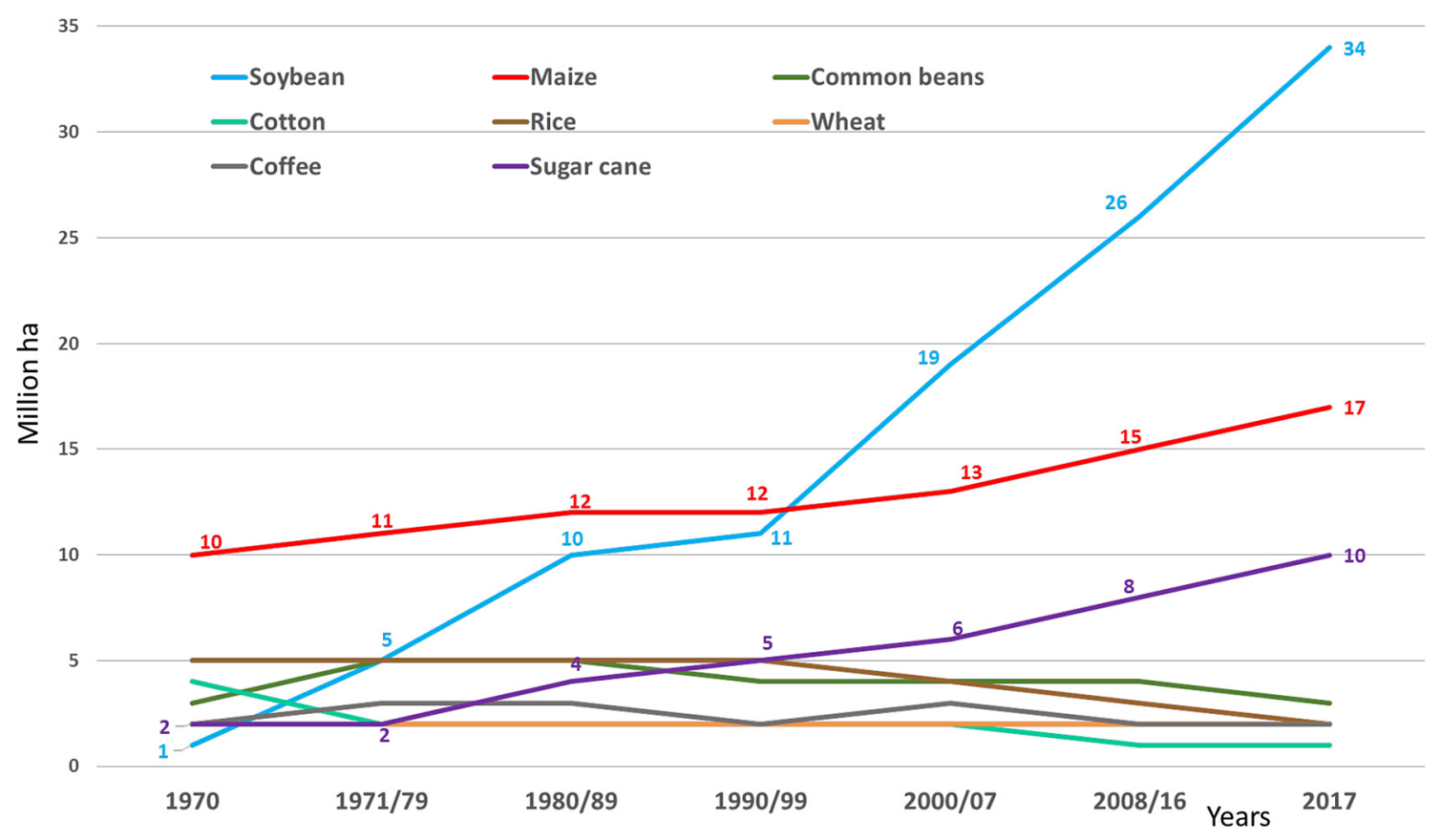

Fig. 3. Main cropping areas in Brazil-1970 to 2017 (Adapted from CONAB, 2017; IBGE, 2017).

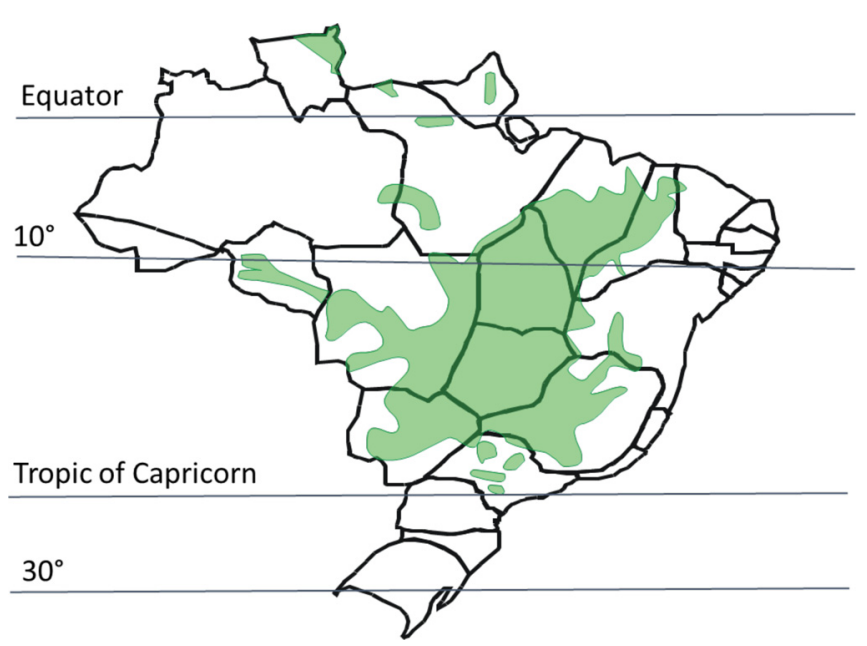

Fig. 4. Geographical distribution of Cerrado lands, the new granary of Brazil (Adapted from IBGE, 2017).

Because Cerrado soils are naturally too acidic and too poor in nutrients, the first step to make them suitable for soybean and agriculture in general was to lime and amend them with macro and micronutrients, following indications of soil analysis. The second step was to develop the tropical soybean, adapted to those conditions. These cultivars are characterized by a long juvenile period, which inhibits the early flowering of soybean under short daylight conditions (low latitude), because they are much less sensitive to photoperiodic variations. This allows soybean to be established successfully in any latitude of the Brazilian territory $\left(5^{\circ} \mathrm{N}\right.$ to $\left.34^{\circ} \mathrm{S}\right)$.

Another turning point was the widespread use of inoculation with nitrogen fixing bacteria (rhizobia), dispensing the use of mineral nitrogen fertilizer. That generates annual savings over than US $\$ 7.0$ billion (Nogueira and Hungria, 2013), and contributes to the reduction of environmental contamination with greenhouse gases and of groundwater with nitrites and nitrates.

Those technological solutions enabled the cultivation of soybean in the Cerrado Region and it allowed the dedicated entrepreneurs who left the south in the quest for success to prosper and become the largest producers of soybean in the country. The social rise of these migrants occurred with little governmental support, and the most efficient ones became modern enterprisers, enjoying, today, a high standard of social and economic life. According to Norman Borlaug, Nobel Peace Prize of 1970, the conquest of Cerrado should be considered one of the major achievements of the 20th century due to the amount of area incorporated into the process of food production (Silva, 2012).

It is noteworthy that, although there are big soybean farms in the Cerrado Region nowadays, some with areas over 10000 ha, most farms are still small or medium size. There are around 216000 soybean producing farms in Brazil, with an average size of 72.45 ha. Of this total, 195000 farms are located in the South Region, with average size of 34.92 ha and 13000 farms in the Midwest Region, with an average size of 501.05 ha (Zanon et al., 2010). It is also noteworthy that the total area cropped with soybean (33.9 Mha or $339000 \mathrm{~km}^{2}$ ) comprises less than $4 \%$ of the total area of the country $\left(8598387 \mathrm{~km}^{2}\right)$.

\section{Evolution of soybean yield}

Average soybean yield continually grew from the 1960 s to the present. Starting from an average yield of $1089 \mathrm{~kg} / \mathrm{ha}$ in 1960/69, Brazil concluded the harvest of the $2016 / 17$ season with a yield of $3362 \mathrm{~kg} / \mathrm{ha}$ (CONAB, 2017). A growth of $208 \%$ (Fig. 5). A record, only surpassed by the 2016 USA average yield ( $3479 \mathrm{~kg} / \mathrm{ha})$, also a historical record (USDA/NASS, 2017). 


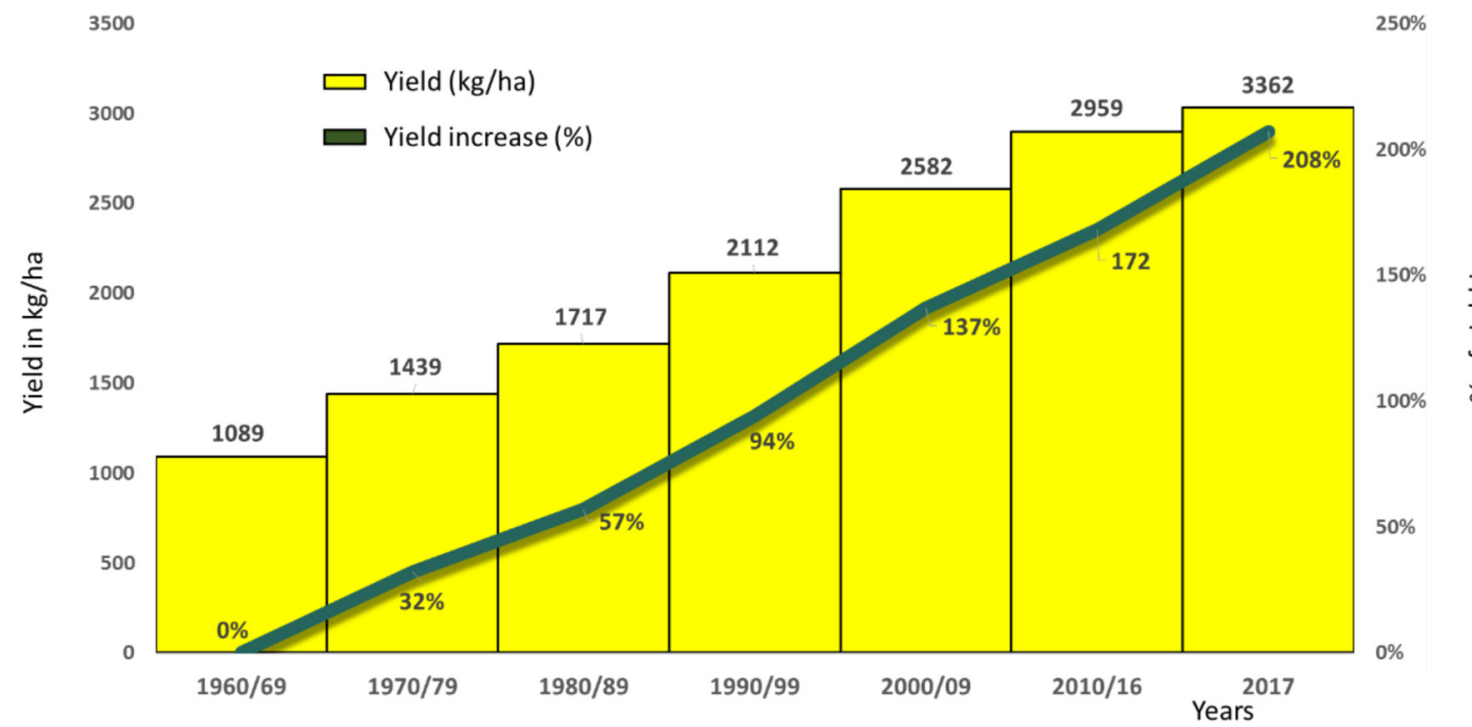

Fig. 5. Soybean yield increase from 1960/69 to 2017 (Adapted from CONAB, 2017).

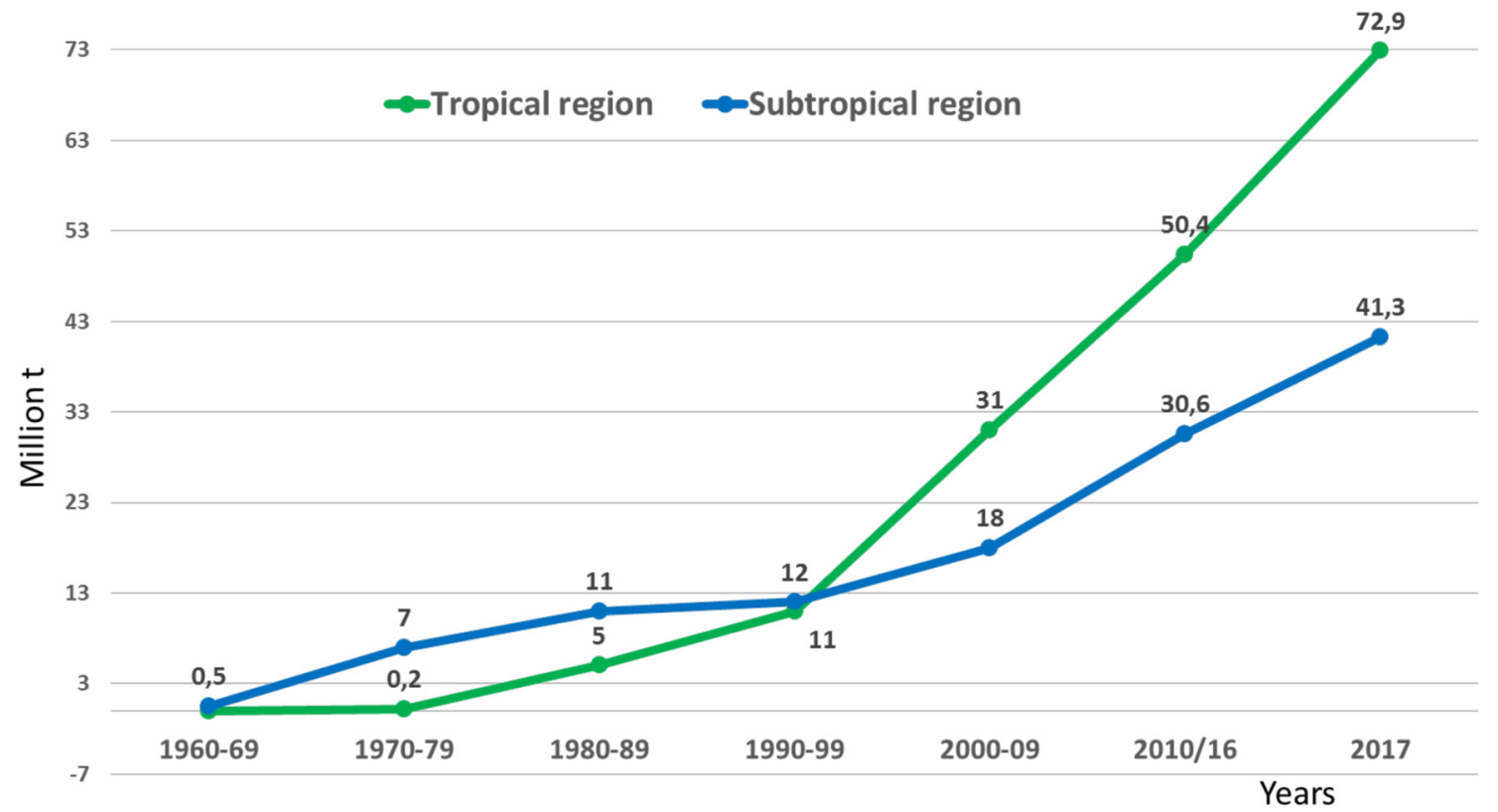

Fig. 6. Soybean production in the Tropics (Midwest Region) vs. Subtropics (South Region) of Brazil (Adapted from CONAB, 2017).

Besides the technologies for the Cerrado occupation, more recently, other technological advances adopted by farmers were also very important, such as the adoption of transgenic soybean which facilitated the weed and insect control; the improvement of planting and harvesting machinery; the implementation of the agro-climatic zoning for the crop; the adoption of precision agriculture by the more advanced farmers; the access of producers to modern technologies in real time-via internet or TV programs directed to the field; the integration of crops with livestock and; especially, the massive adoption of no-till system.

Currently (2017), the Midwest Region grows larger area and produces more soybean than the South Region, the originally traditional production area $(61.8 \%$ vs. $38.2 \%)$, as indicated by Figure 6. Similarly, Figure 7 shows the concentration of Brazilian soybean production in the producing states.

The wide spreading of no-till adoption, in addition to reducing soil erosion, enabled the cultivation of maize as a second crop. That was possible through the strategy of growing early soybean varieties sown in early spring, with harvesting in early summer, followed by maize, which takes advantage of the last rains of the season and ends the cycle with dry weather in the late autumn or beginning of winter. This strategy liberated extensive areas for soybean that were previously cultivated with maize. From 1991 to 2016, the area of first crop maize (spring/summer season) was reduced by $57 \%$, while the area of second crop maize (summer/autumn season) increased almost fifteenfold (Fig 8). The production of second crop 


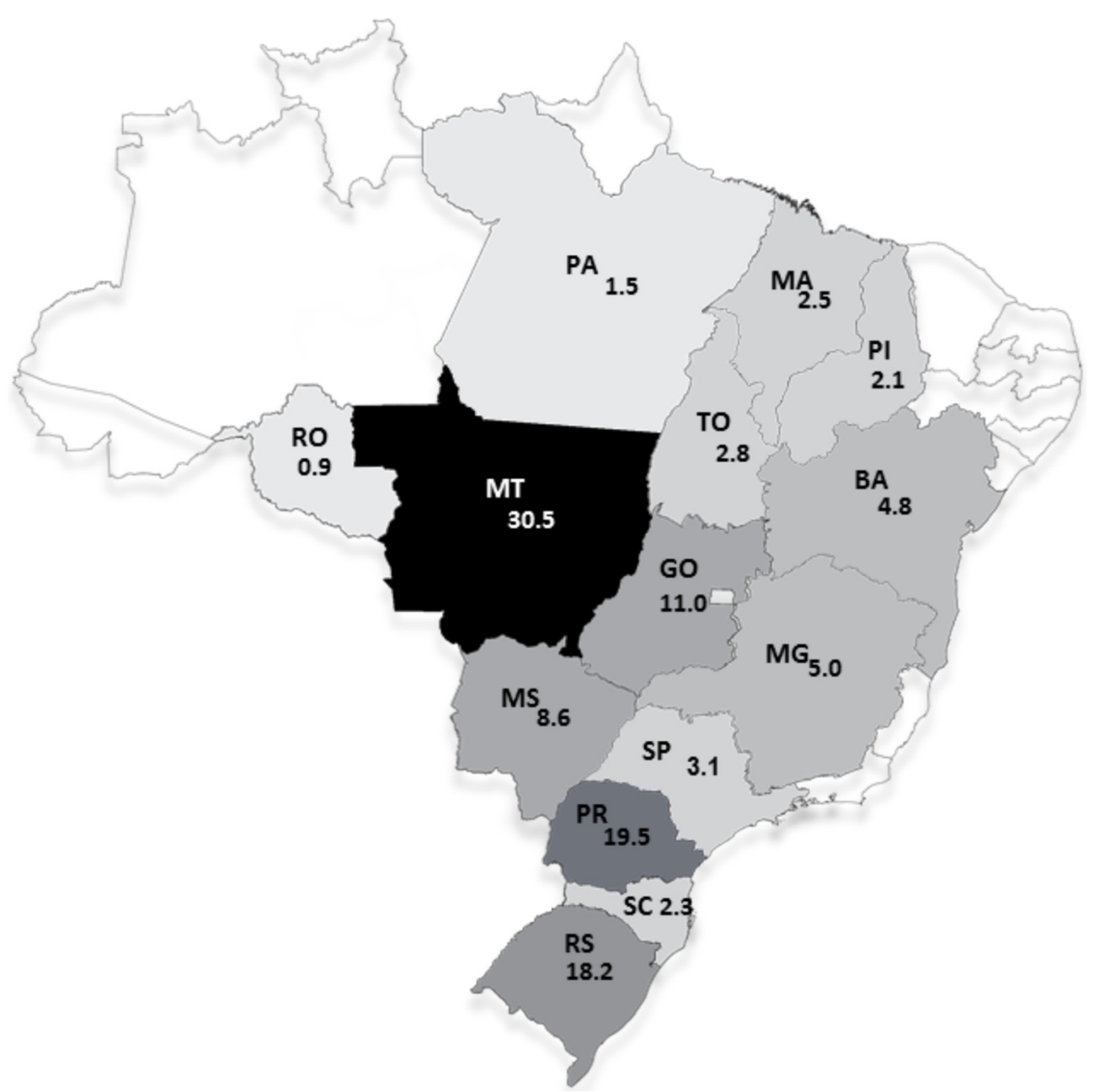

Fig. 7. Soybean production by state (Mt) in the 2016/17 season (Adapted from CONAB, 2017).

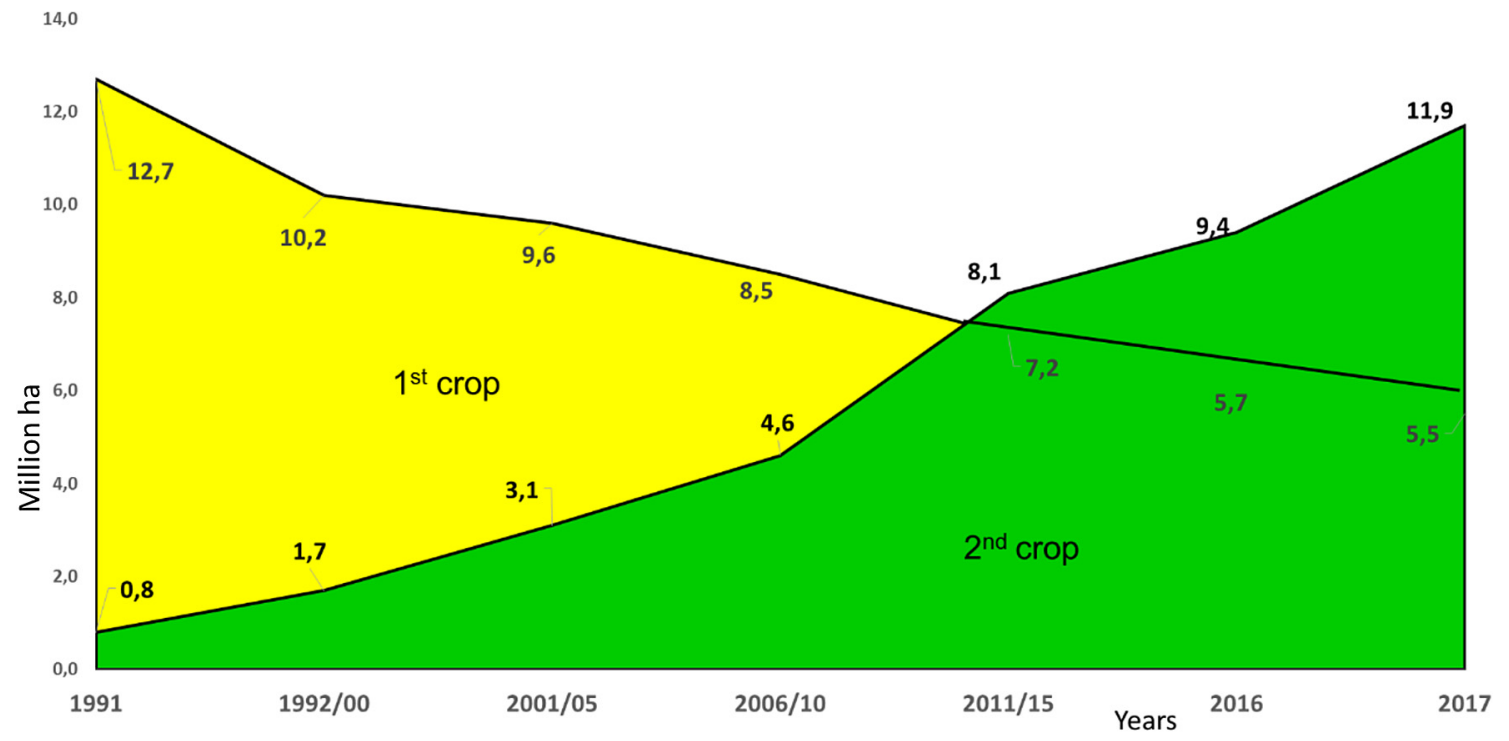

Fig. 8. Cultivated area with maize, first and second crop in Brazil-1991 to 2017. (Adapted from CONAB, 2017). 


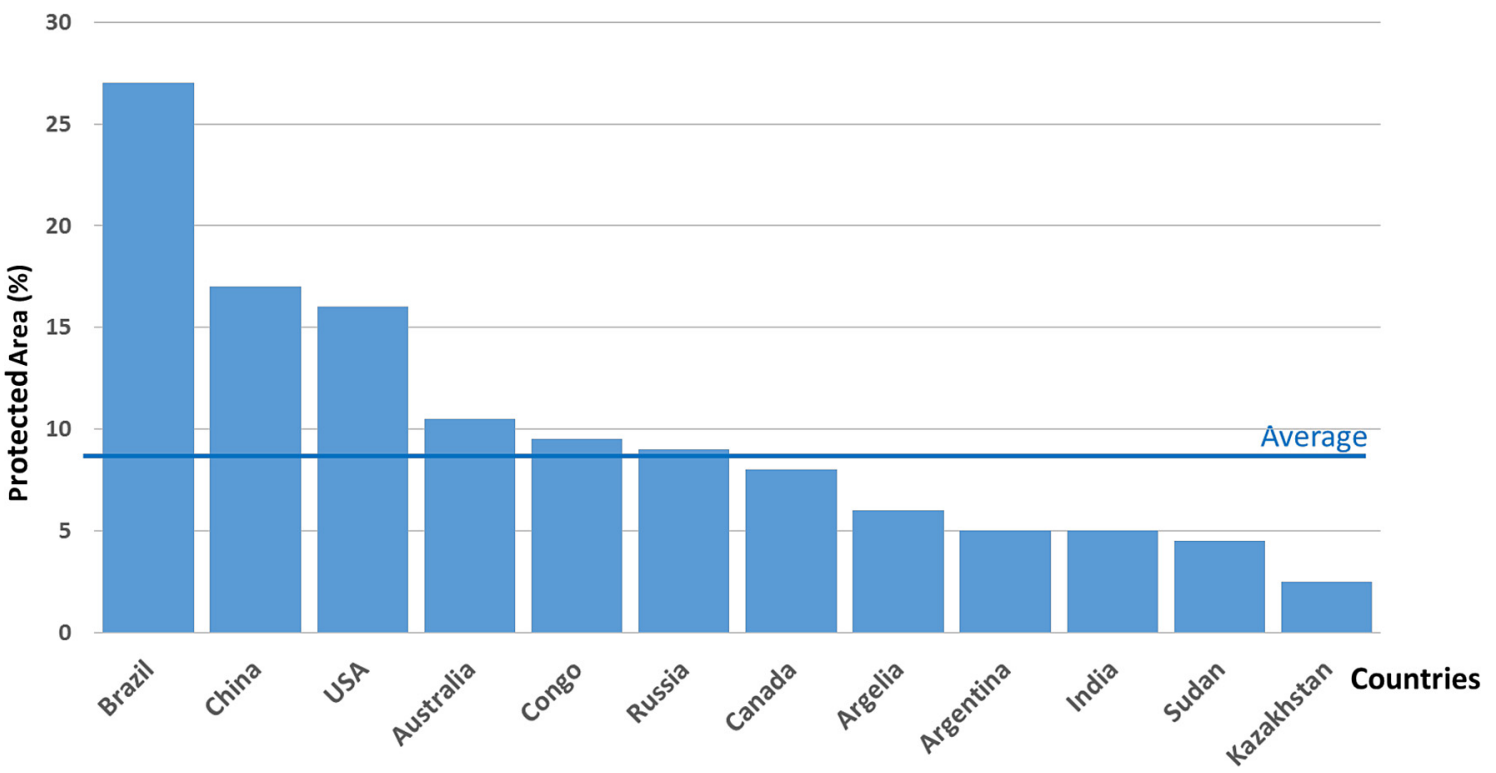

Fig. 9. Preservation lands in countries with territory larger than 2 million $\mathrm{Km}^{2}$ (Adapted from International Union for Conservation of Nature, in Miranda, 2014).

maize, today, exceeds by more than $100 \%$ the production of first crop maize (30.5 Mt vs. $66.7 \mathrm{Mt})$.

\section{Strict land protection legislation}

Brazil has a territory of approximately 860 Mha $\left(8598387 \mathrm{~km}^{2}\right)$ of which only 330 Mha $(38 \%)$ are used for agricultural activities (Miranda, 2014). Conservation Units comprises $17 \%$ of the area (140.5 Mha) and Indigenous protected areas, $13 \%$ (114.7 Mha). Brazilian legislation is quite restrictive regarding the land use. The legislation is particularly protective for the Amazon Biome, where a legal reserve of $80 \%$ is imposed on the landowner, which makes the purchase of Amazonian land for agricultural exploitation virtually impractical. Nevertheless, for areas with vegetation characteristic of the Cerrado Biome but located in the Amazon Region, reservation of $35 \%$, instead of $80 \%$, is required.

In addition to the restriction imposed by the Brazilian legislation on the use of Amazonian soils for soybean cultivation, there is a restriction imposed by the so-called "Soybean Moratorium". The Moratorium is a private initiative sponsored by the Brazilian Association of Vegetable Oil Industries (ABIOVE) and the National Association of Cereal Exporters-ANEC, which together account for the commercialization of more than $90 \%$ of the soybean produced in Brazil. The initiative inhibits soybean cultivation and the sponsors have pledged not to buy or finance soybean crops established in the Amazon Biome after 2008.

Nearly $100 \%$ of the Brazilian soybean produced in the Amazon Biome is being monitored via satellite by the Soybean Working Group (GTS, in Portuguese) created under the auspices of the Moratorium. The GTS is coordinated by the President of ABIOVE and the representative of Greenpeace in Brazil, representing both sides of the table and giving more credibility and trust to the GTS. The GTS is aided by the
National Institute of Space Research (INPE), which through periodic satellite images has the potential to identify soybean farms with more than 25 ha that violate the Moratorium. The results of the satellite monitoring indicate that the participation of soybean cultivation in deforestation occurred after 2008 was extremely low (Kastens et al., 2017).

The Amazon Biome area is multinational. The Brazilian portion (almost five million $\mathrm{km}^{2}$ ) occupies more than half of that territory, which corresponds to $58.4 \%$ of the total area of Brazil. Conflicts over the ownership of these lands are old and still very common. To a large extent, they are associated with problems of deforestation and land ownership. Access to the interior of the forest was possible only through the rivers until the early 1960s, but since then, roads have cut the region and a large number of farmers and pioneers landed there, causing conflicts with adventurers, natives and squatters. Efforts are being made by the government to discipline the use of these lands and end conflicts over ownership.

The Law for Protection of Native Vegetation, popularly known as the New Brazilian Forest Code (Law no. 12.651) became effective in May 2012, as an update of the "old" Brazilian Forest Code of 1965. One of the novelties of the New Code is the Rural Environmental Registry (Cadastro Ambiental Rural-CAR), made electronically, and that is mandatory for all rural properties. Farmers have a deadline to register all their environmental assets by the end of 2017 .

Preliminary results indicate that more than 170 million hectares of native vegetation were preserved by farmers within rural properties, which represents around $20 \%$ of the Brazilian territory (Embrapa, 2017). In all, almost 4 million rural properties were registered in the CAR until December 2016. As registration is still open, these numbers continue to grow.

As a result of the strict legislation and the initiatives of the farmers and the market, the percentage of protected lands in Brazil is much higher when compared to countries with more than 2 million $\mathrm{Km}^{2}$ (Fig. 9). 


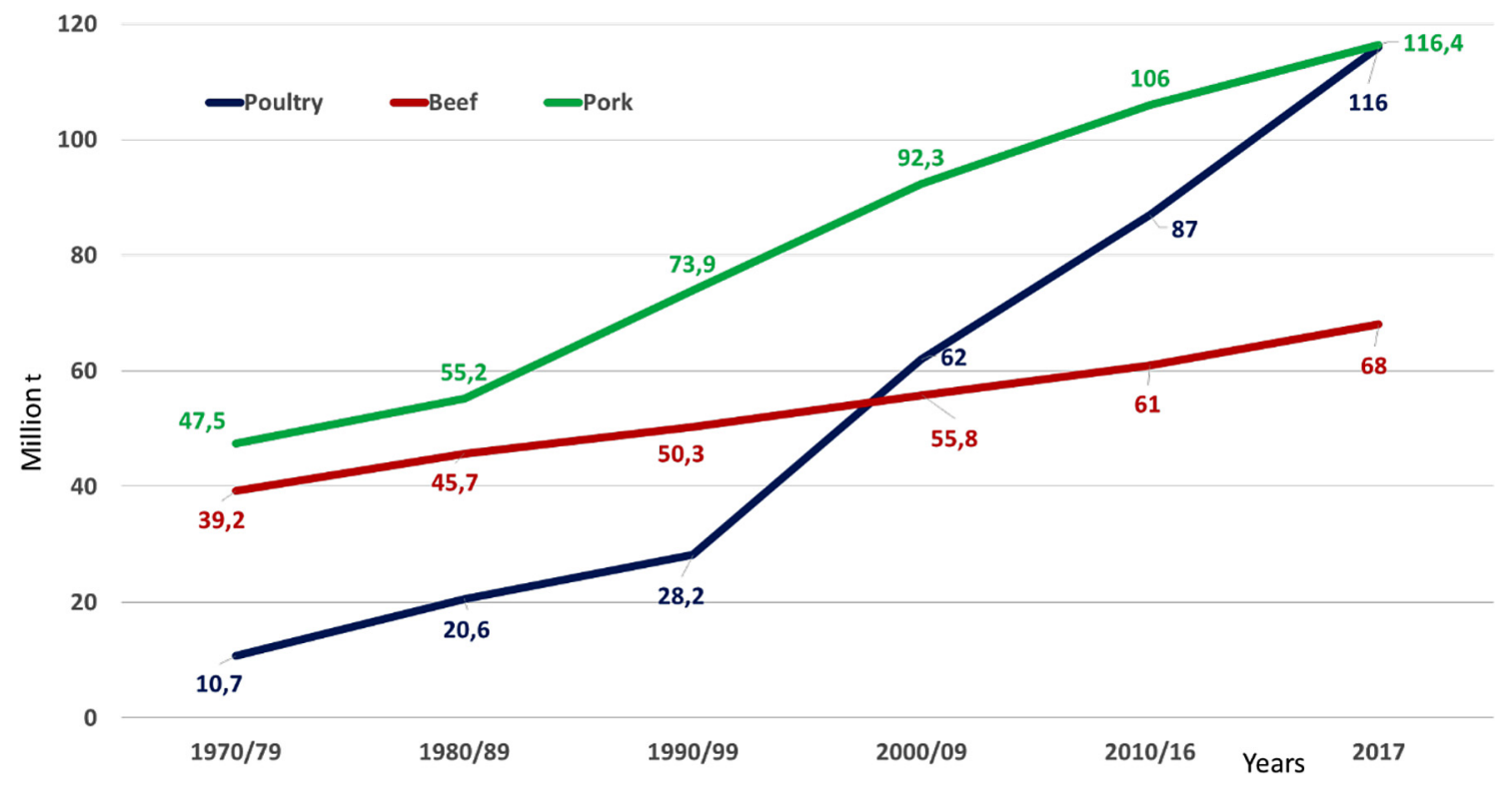

Fig. 10. World production (Mt) of the main meats - 1970/79 to 2017 (Adapted from USDA/FAS, 2017).

\section{Phytosanitary control}

Given the tropical climate and the large cropped area, Brazil faces a huge challenge to control the pests and diseases that affect its production fields. As soybean is mostly cultivated under no-till system, it requires the widespread use of herbicides to desiccate the area, prior to establishing the crop and to control the weeds. Other huge challenge is the soybean Asian rust, a disease extremely aggressive under tropical conditions and, therefore, responsible for the consumption of the major part of the fungicides sprayed in Brazil. To reduce the amount of inoculum of the fungus responsible for the disease (Phakopsora pachyrhizi), Brazil adopts the host-free period (vazio sanitário), a period of 60 to 90 days in which the farmer is prohibited to sow or keep live soybean plants in the field in order to decrease the inoculum of the fungus. In addition, soybean found on highways sides or elsewhere are subject to eradication.

The Brazilian research companies and institutes work intensely in the search for cultivars resistant to Asian rust. To date, they have achieved only partial success, via screening for a handful of known major genes (vertical resistance) or for a combination of many minor genes (horizontal resistance). The resistance achieved so far is only partial, even so, the strategy is important for decreasing the need for fungicide spraying.

It has often been reported that Brazil is one of the largest consumer of agricultural pesticides in the world. According to data from SINDIVEG (Merten, 2016) and Phillips McDougall International Consulting, in 2015 sales of these products in Brazil corresponded to $18.5 \%$ in relation to the world total. It is important to have in mind that Brazil is one of the largest agricultural producers in the world, with around 330 Mha occupied with annual, semi-perennial and perennial crops, planted forests and pastures.

Considering that the amount of commercial agrochemical products used in Brazil in 2015 was 887.6 thousand the correspondent amount of active ingredients (a.i.) estimated was 395.6 thousand $t$ (Merten, 2016). While the growth in the use of agrochemicals in Brazil was $14 \%$ in the last five years, grain production increased $40 \%$ in the same period. It represents lower quantity used per $\mathrm{kg}$ of grain produced $(1.4 \mathrm{~g}$ a.i. $/ \mathrm{kg})$. Considering only the area of grains, coffee, sugarcane, fruits and vegetables, which consumed $96.8 \%$ of the agrochemicals, consumption was $4.99 \mathrm{~kg}$ a.i./ha. However, considering the areas with planted forests and cultivated pastures, consumption was $2.3 \mathrm{~kg}$ a.i./ha. The available data on consumption of agrochemicals in the world show that Brazil uses much less products when compared to the world's largest agricultural producing countries (Merten and Banzato, 2016).

As plant protection products suffer degradation after application and must comply with the grace period (time between last application and harvest), the amount of residue in food is on average very low. This has been confirmed by the residue analyzes in thousands of samples of 25 foods of plant origin representative of the diet of the Brazilian population (ANVISA, 2016).

\section{Soybean production versus meat production}

Global meat production is expected to be $20 \%$ higher in 2025 when compared to the previous decade (OECD/FAO, 2016). Developing countries should be responsible for the majority of the increase in meat production and consumption. In view of this scenario, it is possible to project a growth in world soybean demand, with Brazil as one of the major beneficiaries, given the availability of suitable land for grain production and adequate technologies to produce under tropical conditions.

The volume of the main meats produced in the world (beef, pork and poultry) has been increasing steadily since the middle of the last century, with the highest intensity in the last decades, when it tripled (USDA/FAS, 2017) (Fig. 10). In the same 


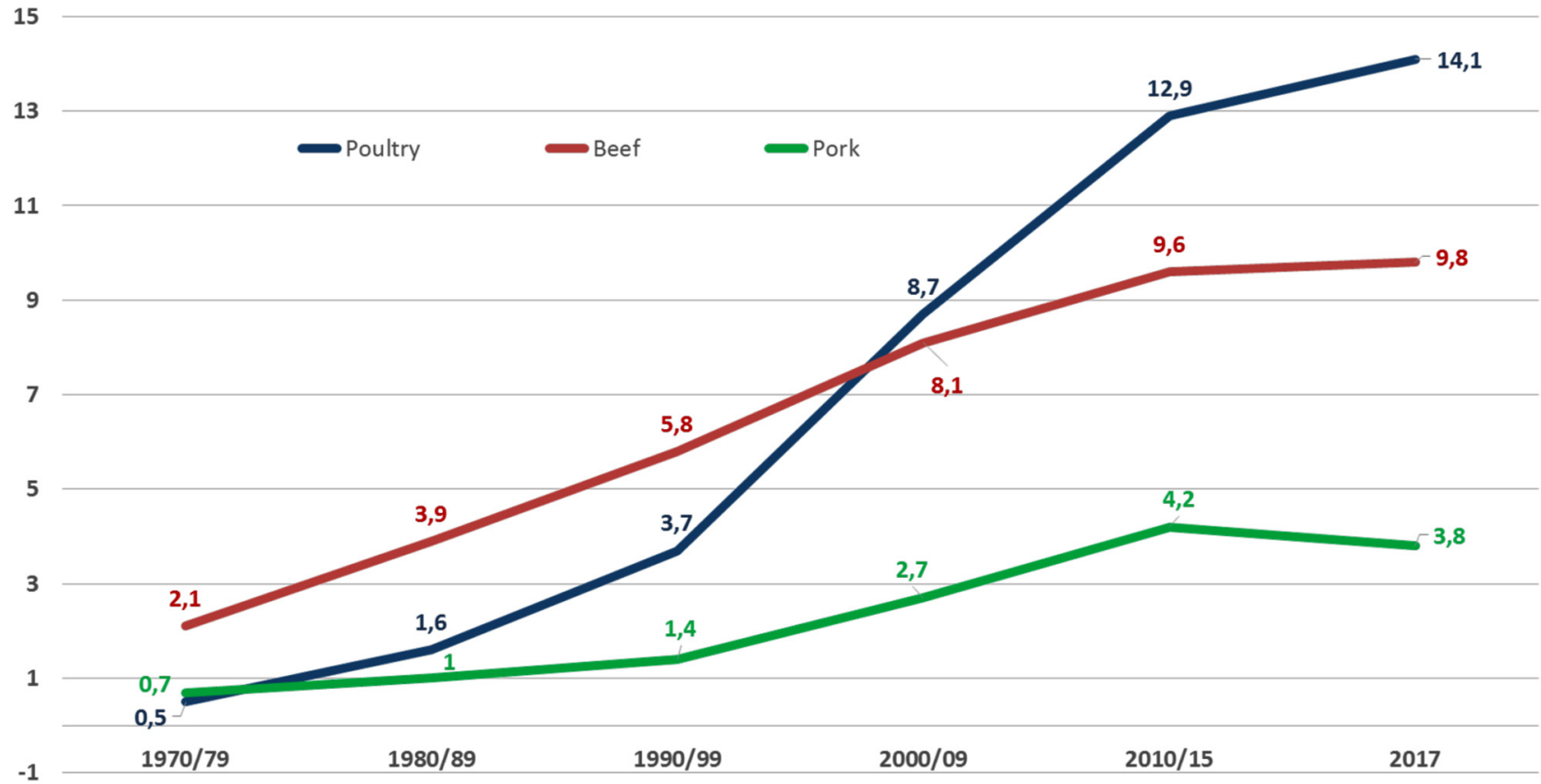

Fig. 11. Brazilian production of the main meats (Mt)-1970/79 to 2017. (Adapted from CONAB, 2017).

period, the Brazilian production of meat grew more expressively and increased eightfold (Fig. 11), making Brazil one of the largest meat producers and exporters (MLA, 2016; USDA/FAS, 2017). The growth was accompanied by similar growth of maize and soybean production. FAO studies indicate that to respond for the meat demands of the global population in year 2050, the current volume of meat should almost double (240 Mt vs. $500 \mathrm{Mt})$ (FAO, 2009).

\section{Importance of the soybean complex for the Brazilian Economy and impacts in the agricultural sector}

Since the early 1970s, soybean has been the driving force behind Brazil's significant agricultural development. It not only came to lead the cropped area and the production of crops in Brazil, as it was elevated to the condition of the main product exported by the country $(14.6 \%$ of the total exported in 2015 , Fig. 12), followed in fifth place by meats $(7.5 \%)$, whose production relies strongly on soybean and maize.

According to the Brazilian Vegetable Oil Industry Association (ABIOVE, 2017), out of the $96.2 \mathrm{Mt}$ of soybean produced in 2016, Brazil exported $51.6 \mathrm{Mt}$ of beans and processed $39.5 \mathrm{Mt}$. Out of the total meal produced, $15.8 \mathrm{Mt}$ were consumed by the national meat industry (mainly pork and poultry) and 14.2 were exported. The oil was mostly consumed internally for biodiesel production and for domestic consumption.

Besides being essential for the generation of foreign exchange via exports, soybeans are the most valuable product of the Brazilian agriculture. In 2017, the crop reached a Gross Production Value (GPV) of US \$ 35.4 billion, corresponding to $21.7 \%$ of the country's agricultural in farm production (MAPA, 2017a).
The Center for Advanced Studies in Applied Economics (CEPEA) of the Luiz de Queiroz College of Agriculture (ESALQ) carried out an initial study to evaluate the Gross Domestic Product (GDP) generated by some of the main productive chains of agriculture and livestock in Brazil. The study shows that the GDP of the soybean production chain reached US \$ 31.6 billion in 2016 , contributing significantly to the economic development of the soybean producing regions (CEPEA, 2017a).

The primary sector and the service sector are the most important in the soybean production chain. On the other hand, the industry sector is the one that contributes the least to the formation of GDP in the production chain (CEPEA, 2017a). A contributing factor is the Kandir Act (Law No. 87) published in September 1996, which exempted goods for export from the payment of the Tax on the Circulation of Goods and Services (ICMS, in Portuguese). After that law, exports of soybean grew exponentially, significantly expanding the foreign trade of the commodity, to the detriment of the manufacturing of valueadded industrial products such as animal feed, biofuels, soybean-based beverages, among countless others (CEPEA, 2017a; MAPA, 2017b). The reflection of this is that the value of Brazilian exports of the soybean agroindustrial complex, especially of grains, has been almost as representative as the GDP of its productive chain, tending to exceed it in the coming years. In other words, the soybean production chain has been as important in generating foreign exchange as in the economic development of the soybean producing regions.

The 216000 farmers who grow soybeans in Brazil are spread all over the country, comprising hundreds of municipalities, with the exception of the Amazon Biome (Zanon et al., 2010). The Human Development Index (HDI) of those municipalities is consistently superior compared to that which do not grow soybean. A study produced by the Kleffmann Group reveals that the municipalities that have agricultural economy presented HDI evolution rates above 


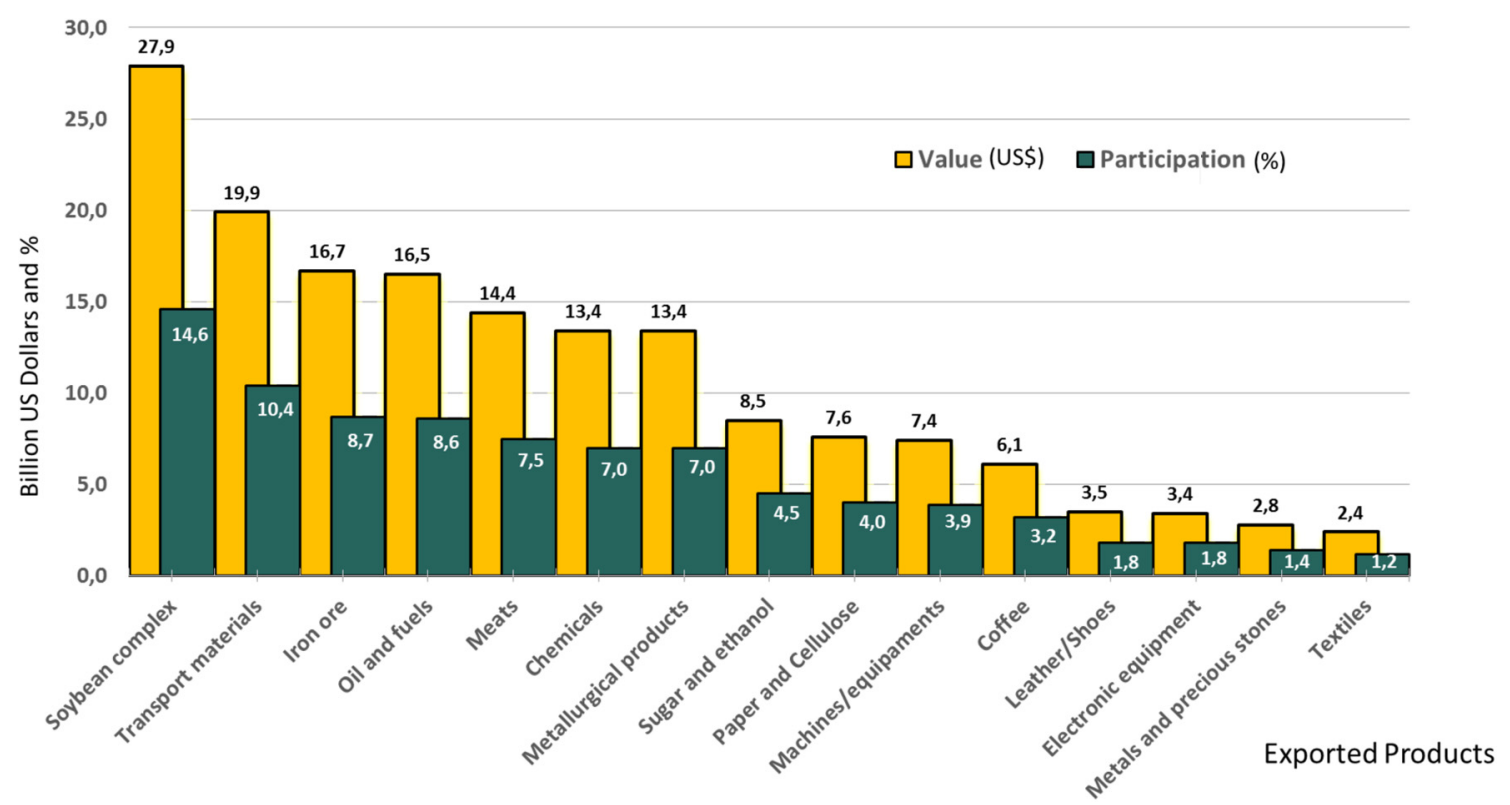

Fig. 12. Soybean in the context of total Brazilian exports (MDIC, 2017).

non-agricultural localities. According to the study, the HDI grew $69 \%$ in agricultural municipalities between 1970 and 2010 (0.424 to 0.718 ) while for non-agricultural localities the growth was only $57 \%$ (Agrolink, 2016; IBGE, 2017).

The remarkable increase in soybean planted area and production over the last few decades has triggered unprecedented changes in the Brazilian agricultural sector. Initially supported by the well-established wheat crop in the south, soybean was the major responsible for the promotion of agribusiness in Brazil, including the expansion and modernization of the transportation system and storage infrastructure for grains; the development of agricultural machinery and its adoption; the expansion of the country's agricultural frontier; the professionalization and increase of international trade; the acceleration of urbanization in Brazil, leading to the emergence of prosperous cities in the crop-producing regions; the stimulation of the population migration to the interior of the territory, uniting the South, Southeast and Northeastern Regions; the technification of other crops and the impulse given to the decentralization of the national agroindustry, particularly meat.

Agribusiness also plays an essential role in the social context, since it has been an important generator of jobs in Brazil. According to the CEPEA/ESALQ study, agribusiness generated 19.1 million jobs in 2015 (CEPEA, 2017b). The primary sector is the main generator of jobs, reaching almost 9.1 million in farm jobs $(47.6 \%$ of the total). The industry and service sector also generated significant amounts of jobs, reaching, respectively, 4.1 and 5.7 million jobs. The only sector that has little representation in the generation of jobs is the agricultural input industry, which generated just under 228 thousand jobs.

\section{Seed industry and biotechnology adoption}

The use of certified seeds for soybean cultivation has evolved rapidly in Brazil in the recent years, even though, 20 to
$25 \%$ of the seeds are non-certified (ABRASEM, 2017). The use of certified seeds is more expressive in the tropical regions, where the climate does not favor its production and conservation. In the subtropics of the South Region, the use of non-certified seeds, including saved seeds (allowed by legislation, Law $\mathrm{N}^{\circ} 10.711,2003$ ), can reach up to $50 \%$ (ABRASEM, 2017).

In the last ten years (2006 to 2016), the national total seed production jumped from $1.8 \mathrm{Mt}$ to $4.0 \mathrm{Mt}$, moving around US \$ 3.0 billion annually (ABRATES, 2017). It makes the Brazilian seed industry the world's third largest, only behind United States and China.

The adoption of biotechnology in Brazil is growing fast. Around $96.5 \%$ of soybean cropped in the $2016 / 17$ season was transgenic or mixed with transgenic. Of this total, $36.7 \%$ had traits for herbicide resistance (Roundup Ready Soybean) and $59.8 \%$ had traits for insect and herbicide resistance (Intacta RR2 Pro Soybean) (Céleres, 2017).

The production of non-GM soybean has experienced a substantial drop in the last years, especially due to the difficulties of keeping the product free from mixtures and the reduction of the premium price paid. Nevertheless, non-GM soybean production in Brazil is still effective in certain regions, especially those located in the far Midwest. This is due to the easy of traceability and the export without contamination using the routes of the regional rivers. The good premium prices recently offered to non-GMs have stimulated producers to invest in this niche market again. Production will only grow if an attractive premium price is guaranteed.

\section{Prospects for Brazilian soybean}

The global food demand will continue to grow during the next decade, although on a smaller scale than in the previous decade, due to the population growth (OECD/FAO, 2017). By 
2030, global demand for food will have increased by at least $35 \%$ (NIC, 2012). Most of the necessary production to fulfill the demand will come from developing countries, especially from Brazil. Although the growth rate of the world population is decreasing, it is offset by the increased life expectancy rate, since the elderly are living longer thanks to improvements in health and life quality. Stability is expected in food demand after 2050 (FAO, 2009), except for animal protein. Meat consumption is expected to increase continuously as a result of the world economy growth, which, even with less vigor than in the recent decades, should continue to grow and maintain the demand for meat and, consequently, for soybean.

Considering that most of the Brazilian soybean is exported to China (74\% in 2016), the growth of that country's economy will be very important for the increase of demand for Brazilian soybeans. The Chinese economy is expected to continue its growth in the next decade, nevertheless, in a lower rate than in the previous years.

The area, production and yield of soybean in Brazil continue to grow. It should lead Brazil to become the world's largest soybean producer, surpassing the United States, in the coming decade (OECD/FAO, 2017). That is because USA no longer has large areas of arable land available to increase production, unless it reduces the cultivated areas with other crops, especially, maize. In Brazil, however, the area planted with soybean may expand even more, using the arable land available in the Midwest Region or recovering degraded or underutilized areas of perennial pastures that are available all over the country.

The challenge for Brazil is to keep the capability to produce soybean in a profitable and sustainable way, as it has been doing so far. Brazil has all it takes to supply the global demand for soybean. The size of the demand and the market prices will determine how much Brazilian soybean production will grow in the coming years.

Acknowledgements. We thank our colleagues from Embrapa Norman Neumaier, Marcelo Hiroshi Hirakuri and Décio Luiz Gazzoni for comments that greatly improved the manuscript and to Vanessa Dall'Agnol for making the graphics.

\section{References}

Agência Nacional de Vigilância Sanitária (ANVISA). 2016. Programa de análise de resíduos de agrotóxicos em alimentos: Relatório das análises de amostras monitoradas no período de 2013 a 2015. Available from http://portal.anvisa.gov.br/documents/111215/0/ Relat $\%$ C3\%B3rio+PARA + 2013-2015 VERS\%C3\%83O-FI NAL.pdf/494cd7c5-5408-4e6a-b0e5-5098cbf759f8 (last consult: 08/24/2017)

Agrolink. 2016. Municípios agrícolas apresentam maior evolução no IDH. Available from https://www.biomassabioenergia.com.br/ imprensa/municipios-agricolas-apresentam-maior-evolucao-noidh/20150218-093418-I306 (last consult: 06/26/2017).

Associação Brasileira das Indústrias de Óleo Vegetal (ABIOVE). 2017. Available from http://www.abiove.org.br/site/index.php? page $=$ estatistica $\&$ area $=\mathrm{NC0yLTE}=($ last consult: 06/14/2017).

Associação Brasileira de Sementes e Mudas (ABRASEM). 2017. Anuário 2016. Available from http://www.abrasem.com.br/wpcontent/uploads/2013/09/Anuario_ABRASEM_2016_SITE.pdf (last consult: 11/21/2017).
Associação Brasileira de Tecnologia de Sementes (ABRATES). 2017. Mercado de sementes movimenta $\mathrm{R} \$ 10$ bi ao ano no Brasil. Available from http://www.abrates.org.br/noticia/mercado-desementes-movimenta-r-10-bi-ao-ano-no-brasil (last consult: 11/ 21/2017).

Céleres. 2017. $3^{\circ}$ levantamento de adoção de biotecnologia agrícola no Brasil, safra 2016/17. Available from http://www.celeres.com. br/3o-levantamento-de-adocao-da-biotecnologia-agricola-no-bra sil-safra-201617/ (last consult: 11/21/2017).

Centro de Estudos Avançados em Economia Aplicada (CEPEA). 2017a. PIB de cadeias agropecuárias. Available from https:// www.cepea.esalq.usp.br/br/pib-de-cadeias-agropecuarias.aspx (last consult 11/17/2017).

Centro de Estudos Avançados em Economia Aplicada (CEPEA). 2017b. O mercado de trabalho do agronegócio brasileiro. Resultados preliminares: 2015. Available from https://www. cepea.esalq.usp.br/br/documentos/texto/mercado-de-trabalhodo-agronegocio-brasileiro-resultados-preliminares.aspx (last consult 11/17/2017).

Companhia Nacional de Abastecimento (CONAB). 2017. Séries Históricas. Available from http://www.conab.gov.br/conteudos. php?a=1252 (last consult: 08/31/2017).

Dall'Agnol A. 2016. A Embrapa Soja no contexto do desenvolvimento da soja no Brasil-Histórico e contribuições. Brasília: Embrapa.

Empresa Brasileira de Pesquisa Agropecuária (Embrapa). 2017. Agricultura e Preservação Ambiental-Uma primeira análise do Cadastro Ambiental Rural. Available from https://www.cnpm. embrapa.br/projetos/car/index.html (last consult: 06/16/2017).

Food and Agriculture Organization of the United Nation (FAO). 2009. Global agriculture towards 2050. Available from http://www.fao. org/fileadmin/templates/wsfs/docs/Issues_papers/HLEF2050_ Global_Agriculture.pdf (last consult: 06/16/2017).

Goodland R. 1971. A physiognomic analysis of the 'cerrado' vegetation of central Brazil. J Ecol 59: 411-419.

Instituto Brasileiro de Geografia e Estatística (IBGE). 2017. Available from https://sidra.ibge.gov.br/home/pmc/brasil (last consult: 06/ 13/2017).

Kastens JH, Brown JC, Coutinho AC, Bishop CR, Esquerdo JCDM. 2017. Soy moratorium impacts on soybean and deforestation dynamics in Mato Grosso, Brazil. Plos One 12(4): e0176168. Available from https://doi.org/10.1371/journal.pone.0176168 (last consult: 06/19/2017).

Meat \& Livestock Australia (MLA). 2016. India leading global beef exports. Available from https://www.mla.com.au/prices-markets/ market-news/india-leading-global-beef-exports/ (last consult: 06/ 16/2017).

Merten JO. 2016. Consumo de produtos fitossanitários no Brasil. Available from http://sindiveg.org.br/consumo-de-produtos-fitos sanitarios-no-brasil/ (last consult: 06/ 16/2017).

Merten JO, Banzato TC. 2016. Setor de produtos fitossanitários no Brasil. Available from http://www.esalq.usp.br/departamentos/ leb/disciplinas/Casimiro/LFN/AULA\%20ESALQ\%20-\% 20SETOR\%20DE\%20PRODUTOS\%20FITOSSANITARIOS\% 20-20agosto\%202016.pdf (last consult: 06/16/2017).

Ministério da Agricultura, Pecuária e Abastecimento (MAPA). 2017a. Valor bruto da produção agropecuária (VBP). Available from http://www.agricultura.gov.br/assuntos/politica-agricola/valorbruto-da-producao-agropecuaria-vbp (last consult: 11/21/2017).

Ministério da Agricultura, Pecuária e Abastecimento (MAPA). 2017b. AGROSTAT-Estatísticas de Comércio Exterior do Agronegócio Brasileiro. Available from http://indicadores.agri cultura.gov.br/agrostat/index.htm (last consult: 11/21/2017). 
Ministério da Indústria, Comércio Exterior e Serviços (MDIC). 2017. Exportação 2016/2015. Available from http://www.mdic.gov.br/ comercio-exterior/estatisticas-de-comercio-exterior/balancacomercial-brasileira-acumulado-do-ano/2-uncategorised/2205balanca-comercial-janeiro-dezembro-2016 (last consult: 06/13/ 2017).

Miranda EE de. 2014. A questão fundiária brasileira e o potencial do aumento das áreas produtores de grãos. Available from http:// evaristodemiranda.com.br/wp-content/uploads/2014/08/ 140826_AGROCERES_versaowebsite.pdf (last consult: 06/14/ 2017).

National Intelligence Council (NIC). 2012. Global Trends 2030: Alternative Worlds. Available from http://www.dni.gov/files/ documents/GlobalTrends_2030.pdf (last consult: 06/16/2017).

Nogueira MA, Hungria M. 2013. Oportunidades e ameaças à contribuição da fixação biológica de nitrogênio em leguminosas no Brasil. In: Iberoamerican Conference on Beneficial PlantMicroorganism - Environment Interactions, 2; National Meeting of the Spanish Society of Nitrogen Fixation, 14; Latin American Meeting on Rhizobiology, 26; Spanish-Portuguese Congress on Nitrogen Fixation, 3. Sevilla (Spain): Universidad de Sevilla, 2013. Organisation for Economic Co-operation and Development (OECD)/ Food and Agriculture Organization of the United Nations (FAO).
2016. Agricultural Outlook 2016-2025. Available from https:// doi.org/10.1787/agr outlook-2016-en (last consult: 06/16/2017).

Organisation for Economic Co-operation and Development (OECD)/ Food and Agriculture Organization of the United Nations (FAO). 2017. Agricultural Outlook 2017-2026: Special focus: Southeast Asia. Available from http://www.fao.org/3/a-i7465e.pdf (last consult: 07/14/2017).

Silva CM. 2012. Science, Agriculture and Nation Building: IRI Research Institute (IRI) and the Conquest of the "Campos Cerrados" in Brazil (1946-1980). Available from http://rockarch. org/publications/resrep/dasilva.pdf (last consult: 08/25/2017).

United States Department of Agriculture (USDA)/Foreign Agricultural Service (FAS). 2017. Livestock and Poultry: World markets and trade. Available from https://apps.fas.usda.gov/ psdonline/circulars/livestock_poultry.pdf (last consult: 06/16/ 2017).

United States Department of Agriculture (USDA)/National Agricultural Statistics Service (NASS). 2017. Available from https:// www.nass.usda.gov/ (last consult: 06/13/2017).

Zanon RS, Saes MSM, Corrar LJ, Macedo MA. 2010. Produção de soja no Brasil: principais determinantes do tamanho das propriedades. Available from http://www.sober.org.br/palestra/ 15/38.pdf (last consult: 06/26/2017).

Cite this article as: Cattelan AJ, Dall'Agnol A. 2018. The rapid soybean growth in Brazil. OCL 25(1): D102. 